\title{
Efficacy of bivalent vaccine against black body syndrome (BBS) of barramundi Lates calcalifer B.
}

\section{Efikasi vaksin bivalen untuk pencegahan penyakit black body syndrome (BBS) pada ikan kakap putih Lates calcalifer B.}

\author{
Anis Nugrahawati ${ }^{1}$, Sri Nuryati ${ }^{2}$, Sukenda $^{2}$, Rahman $^{2}$, Margie Brite ${ }^{3}$, Tiya Widi Aditya ${ }^{3}$ \\ ${ }^{1}$ Aquaculture science, Department of Aquaculture, Faculty of Fisheries and Marine Science, IPB University (Bogor \\ Agricultural University), Dramaga, West Java, Indonesia 16680 \\ ${ }^{2}$ Department of Aquaculture, Faculty of Fisheries and Marine Science, IPB University (Bogor Agricultural \\ University), Dramaga, West Java, Indonesia 16680 \\ ${ }^{3}$ Centre for Mariculture Research Development, Lampung \\ *Corresponding author: sri.nuryati606@gmail.com
}

(Received January 31, 2018; Accepted May 10, 2019)

\begin{abstract}
Black body syndrome causes mass mortality in barramundi (Lates calcarifer) in Asia mariculture. This study aimed to evaluate the efficacy of bivalent vaccine derived from local isolate for black body syndrome (BBS) prevention on the Barramundi. The bacteria used in the bivalent vaccine were Pseudomonas stutzeri and Vibrio harveyi in a ratio of 50:50. Barramundi, 5-6 cm in length, was intraperitoneally injected with bivalent vaccine and phosphate buffer saline (PBS). After a 21-day vaccination, fish was injected with pathogenic bacteria $P$. stutzeri, V. harveyi, the combination of $P$. stutzeri and $V$. harveyi with a dose of bacteria $107 \mathrm{CFU} /$ fish. We observed relative percent survival (RPS), mortality, blood profile, antibody level, lysozyme activity, and histopathology of vaccinated fish. The result showed that vaccinated fish had higher antibody levels and lysozyme activity than control treatment $(\mathrm{P}>0.05)$. Vaccinated fish had RPS of $80.00 \%, 64.29 \%, 57.69 \%$, after challenged test with P. stutzeri, V. harveyi, and combination of P. stutzeri and $V$. harveyi, respectively. Hemoglobin and hematocrit were not significantly different $(\mathrm{P}>0.05)$. However, the erythrocytes, leucocytes, and phagocytic activity were higher compared to there were higher erythrocytes, leucocytes, and phagocytic activity compared to control $(\mathrm{P}<0.05)$. As well as antibody level and lysozyme activity of vaccinated fish higher than control $(\mathrm{P}<0.05)$. In conclusion, the bivalent vaccine of $P$. stutzeri and $V$. harveyi could protect barramundi seed from BBS infection.
\end{abstract}

Keywords: Lates calcalifer, bivalent vaccine, local isolate, Pseudomonas stutzeri, Vibrio harveyi

\begin{abstract}
ABSTRAK
Black body syndrome menyebabkan kematian masal pada ikan kakap putih budidaya air laut di wilayah Asia. Tujuan dari penelitian ini adalah untuk menguji efikasi vaksin bivalen untuk penanggulangan black body syndrome pada benih ikan kakap putih. Bakteri yang digunakan untuk membuat vaksin bivalen yaitu Pseudomonas stutzeri dan Vibrio harveyi dengan rasio 50:50. Ikan kakap putih berukuran 5-6 cm diinjeksi vaksin bivalen dan phosphat buffer saline secara intraperitoneal. Setelah 21 hari pemeliharaan, benih diuji tantang dengan bakteri patogen P. stutzeri, V. harveyi, campuran P. stutzeri dan V. harveyi dengan kepadatan bakteri sebesar 107 CFU/ikan. Parameter yang diamati meliputi relative percent survival (RPS), gambaran darah, titer antibodi, aktifitas lisosim, dan gambaran histopatologi benih kakap putih. Hasil penelitian menunjukkan bahwa ikan yang divaksin memiliki nilai titer antibodi dan aktifitas lisosim lebih tinggi dibandingkan kontrol $(\mathrm{P}<0.05)$. Ikan yang divaksin memilki RPS $80.00 \%, 64.29 \%, 57.69 \%$, setelah diuji tantang dengan P. stutzeri, V. harveyi, campuran P. stutzeri dan V. harveyi. Nilai hemoglobin dan hematokrit tidak berbeda nyata $(\mathrm{P}>0.05)$. Titer antibodi dan aktifitas lisosim ikan yang divaksin lebih tinggi dari kontrol $(\mathrm{P}<0.05)$. Vaksin bivalen $P$. stutzeri dan $V$. harveyi dapat melindungi benih ikan kakap putih dari infeksi BBS.
\end{abstract}




\section{INTRODUCTION}

Barramundi or Asian seabass is a commercially important aquaculture species in south-east Asia and Australia. Barramundi is widely distributed in marine, freshwater, and brackish coastal environment and is a demersal catadromous fish. Production of the fish has progressively increased in the past years (Siddik et al., 2016; Venkatachalam et al., 2018). Other than that, new technological advances and increased demands for fish as a source of animal protein are the main reasons for the industry's growth. Expansion of the industry caused more intensive culture methods for producing higher yields (Rico et al., 2012). Recently the sector attracted great attention and it is growing rapidly through the development of aquaculture, and intensification in the activity of barramundi fish farming increases the risk of environmental pollution that can lead to an outbreak disease (Dong et al., 2017; Kubecka et al., 2016; Sharma et al., 2012; Ransangan \& Manin, 2010). Hamed et al. (2018) stated that the appearance and development of fish diseases were the results of the interactions among pathogens, hosts, and the environment. Deteriorating environmental conditions causes new diseases popping up and causing huge losses.

In recent years an emerged disease attacks barramundi seed with clinical symptoms such as blackening body, passive movement, low appetite, bleeding in the lower abdomen, as well as liver, kidney, and the spleen of the barramundi seed turns pale caused by $P$. stutzeri and $V$. harveyi attack. This is following Ransangan and Saleem (2009); Ransangan et al. (2012) stated that bacterial infections caused many deaths and high losses on the culture of barramundi. The bacterial attack is inseparable from bacterial properties they have, as an example, the opportunistic bacteria such as Vibrionaceae and Pseudomonadaceae, a dominant halophilic bacteria, are pathogenic bacteria to marine organisms and also human.

Assefa and Abunna (2018) mentioned that the emergence of disease outbreak could cause considerable losses in fish cultivation, thus it required effective action and appropriate bacterial disease control. The use of antibiotics cannot be tolerated because it potentially harm and it is not environmentally friendly. Ozturk and Altinok (2014); Wali and Balkhi (2016) stated that prevention of disease is preferable to disease treatment, both infectious and noninfectious outbreaks. Beyond that, correct diagnosis and environmentally acceptable treatment methods should be carried out. Disease prevention using fish submersion method in water and liquid antiseptic is considered ineffective, so it requires other methods to control the disease.

Vaccination is an attempt to produce specific antibody, safe and effective that can be used for the sustainable development aquaculture industry (Evensen \& Leong, 2013). In response to reduced antibiotic use in fish, production vaccines have been playing a key role in infectious disease control in aquaculture for decades. Vaccines get wide acceptance for the fact there is no risk of drug resistance development in vaccinated animals (Assefa \& Abunna, 2018). BBS caused by an infection of various bacteria such as $P$. stutzeri, V. harveyi, Bacillus cereus, and Salinococcus roseus. Based on the five bacteria, $P$. stutzeri and $V$. harveyi is the most pathogenic and showed clinical symptoms of BBS in the tested fish (Izwar, 2018). Therefore, for controlling this disease should be developed a polyvalent vaccine, as well as on specifically aimed at testing the immunogenicity and protection of vaccinated barramundi.

\section{MATERIALS AND METHODS}

\section{Time and place}

The study was conducted from February 2017 to August 2017 at the Laboratory of Aquatic Organism Health, Department of Aquaculture, Faculty Fisheries and Marine Sciences, Bogor Agricultural University and the Centre for Mariculture Research Development (BBPBL) Lampung.

\section{Fish test}

Seeds of 5-6 $\mathrm{cm}$ barramundi fish obtained from the cultivators in the barramundi Kalianda area, South Lampung. All the fish were tested by examining the outer conditions of fish and internal organs of the fish, such as kidneys, liver, and crushed spleen then scraped into the agar medium, if there were no bacteria then the fish was safe to use. Fish was kept in aquarium size $40 \times 40 \times 60$ $\mathrm{cm}^{3}$ with a density of 1 fish per liter. Barramundi seed was adapted to the environmental conditions and feed for one week using commercial pellets provided at satiation.

\section{Experimental design}

This study consisted of the treatment of barramundi which was bivalent and vaccinated 
Table 1. The design of the challenge test on barramundi seed after vaccination

\begin{tabular}{cl}
\hline Treatment & \multicolumn{1}{c}{ Information } \\
\hline V1 & The seed was vaccinated with bivalent vaccine and challenged with $P$. stutzeri \\
V2 & The seed was vaccinated with bivalent vaccine and challenged with $V$. harveyi \\
Vg & $\begin{array}{l}\text { The seed was vaccinated with bivalent vaccine and challenged with mix bacteria } P \text {. stutzeri and } \\
\text { V. harveyi }\end{array}$ \\
Vk & The seed was vaccinated with bivalent vaccine and challenged with PBS \\
K1 & The seed was injected with PBS and challenged with $P$. stutzeri \\
K2 & The seed was injected with PBS and challenged with $V$. Harveyi \\
Kg & The seed was injected with PBS and challenged with mix bacteria P. stutzeri dan $V$. harveyi \\
Kk & The seed was injected with PBS and challenged with PBS \\
\hline
\end{tabular}

seeds injected by phosphate buffer saline (PBS) as control and treatment of challenge tests with single bacteria and bacteria combined. The design of the challenge test treatment is presented below in Table 1 .

\section{Vaccine making test}

The formalin-killed cell (FKC) vaccine from each of the bacteria was made by reference from Kumaran etal.(2010). The single bacterial vaccine with each concentration of $10^{\circ} \mathrm{CFU} / \mathrm{mL}$ was then mixed with a 50:50 ratio to get the bivalent vaccine $P$. stutzeri and $V$. harveyi. Vaccines were packed in bottles and stored in cabinets in low temperature until used.

\section{Seed vaccination}

A total of 200 barramundi seeds were injected through intraperitoneal using a $0.1 \mathrm{~mL} / \mathrm{ind}$ of bivalent vaccine, while the control fish group was injected with a PBS solution of $0.1 \mathrm{~mL} / \mathrm{ind}$. The next fish was kept for 21 days.

\section{Challenge test}

The seed test was performed on the $22^{\text {nd }}$ day after vaccination with pathogenic bacteria $P$. stutzeri, $V$. harveyi, and the combination of $P$. stutzeri and $V$. harveyi using $0.1 \mathrm{~mL}$ with a bacterial density of $10^{7} \mathrm{CFU} / \mathrm{mL}$ (corresponding to a dose of LD50) of $0.1 \mathrm{~mL} / \mathrm{ind}$. The seed was reared in an aquarium with a stocking density of 15 fish/aquarium. Mortality and RPS seeds were observed until seven days after the challenge test.

\section{Parameter of research}

The observed parameters were relative percent survival (RPS), mortality, blood profile, antibody titers, lysozyme activity, and liver histopathology.
Relative percent survival (RPS)

The calculation of RPS value was done at the end of the research to determine the effectiveness of the applied vaccine. RPS was calculated using (1988) formulation:

$$
\text { RPS }=1-\left[\frac{\text { Percent mortality in treated group }}{\text { Percent mortality in control group }}\right] \times 100
$$

\section{Blood view observation}

The blood sample was taken from caudal fin veins. Observation of blood profile parameters consisted of erythrocyte cell counts, leukocyte count, hemoglobin, hematocrit, and phagocytic activity. Total erythrocytes and leukocyte were calculated using the method of Blaxhall and Daisley (1973). Hemoglobin levels were measured by Sahli method (Wedemeyer \& Yasutake, 1977). The hematocrit was measured using the Anderson and Siwicki (1993) methods. Phagocytic activity was calculated based on the Anderson and Siwicki (1993) methods.

\section{Antibody testing}

Testing of antibody titer was performed on a 96-wells microplate-based on a method referred to Takahashi et al. (2014). Measurement of antibody titer was performed by taking $25 \mu \mathrm{L}$ of PBS solutions and put into microplate at holes 1 to 12 , then inserted blood serum in the hole 1 as much as $25 \mu \mathrm{L}$. Series of dilution were performed from hole 1 to 11 . A $25 \mu \mathrm{L}$ of bacterins were inserted into holes 1 to 12 . Furthermore, it was stored for two hours in the incubator at $37^{\circ} \mathrm{C}$, followed by saving it in the $4^{\circ} \mathrm{C}$ refrigerator for 24 hours. The antibody titer was determined from the last remaining hole an agglutination reaction was found. 


\section{Lysozyme activity}

The lysozyme activity was measured by the method by Ellis (1990). Lysozyme activity was limited to several enzymes that caused a decrease in absorbance of $0.001 / \mathrm{min}$. Here is the lysozyme calculation formula:

$$
\text { Lysozyme activity }\left(\text { unit/mL) }=\frac{\frac{(\text { initial OD-final OD }) \times 1000}{\text { final time measurement }}}{\text { sample volume }}\right.
$$

\section{Data analysis}

This research used a completely randomized design. All data were tabulated with Microsoft Office Excel 2013. The RPS data, blood profile, antibody titers, and lysozyme activity were analyzed using ANOVA with SPSS 24.0 at a significant level of $95 \%$. A significant result would be analyzed further using a post-hoc Duncan $>$ s test. Histopathology data were analyzed descriptively.

\section{RESULTS}

\section{Mortality rate and relative percent survival (RPS) seed of barramundi}

The mortality rate of barramundi seeds injected with the bivalent vaccine was significantly greater $(\mathrm{P}<0.05)$ than control until day 29, so did the value of RPS vaccinated fish $(\mathrm{P}<0.05)$ compared with the control treatment on the $29^{\text {th }}$ day of rearing. These results showed that the administration of the vaccine was effective in maintaining the survival of the barramundi infected with high pathogenicity bacteria.

\section{The profile of barramundi seeds blood after vaccination and challenge test}

The hematocrit value of day 7 after vaccination did not significantly different between all treatments $(P>0.05)$. However, there were differences in total erythrocytes, leucocytes, hemoglobin, and phagocytic activity. Hematocrit seeds ranged from 13.10 to $15.91 \%$. Total erythrocytes, leucocytes, hemoglobin, and phagocytic activity of barramundi seeds higher vaccine treatment compared with control and initial treatment (before vaccination) $(\mathrm{P}<0.05)$. The overview blood profile of barramundi seed 21 days after vaccination is presented in Table 3.

The blood profile of barramundi seed at seven days post-challenge between groups of fish vaccines and fish controls, each of which was tested against $P$. stutzeri, $V$. harveyi, the combination of $P$. stutzeri and $V$. harveyi, as well as the controls gave distinctly different values $(\mathrm{P}<0.05)$ in total erythrocytes, leucocytes, and phagocytic activity, whereas in hemoglobin values group vaccine fish treatment ranged from 11.00 to $12.00 \mathrm{~g} / \mathrm{dL}$ was not significantly different $(\mathrm{P}>0.05)$ with control group of fish that ranged between $10.33-11.33 \mathrm{~g} / \mathrm{dL}$ and hematocrit group

Table 2. Mortality rate and RPS of vaccinated barramundi seed

\begin{tabular}{cccc}
\hline Treatment & Challenge test & Mortality $(\%)$ & RPS $(\%)$ \\
\hline \multirow{2}{*}{ Vaccine } & P. stutzeri & $16.67 \pm 3.85^{\mathrm{a}}$ & $80.00 \pm 3.70^{\mathrm{b}}$ \\
& V. harveyi & $33.33 \pm 3.84^{\mathrm{b}}$ & $64.29 \pm 5.10^{\mathrm{a}}$ \\
& Combination & $36.67 \pm 3.85^{\mathrm{b}}$ & $57.69 \pm 2.28^{\mathrm{a}}$ \\
\multirow{2}{*}{ Control } & P. stutzeri & $83.33 \pm 3.85^{\mathrm{c}}$ & - \\
& V. harveyi & $93.33 \pm 3.84^{\mathrm{cd}}$ & - \\
\hline
\end{tabular}

Note: Different superscript on the age of seeds and the same parameters show an influence The treatment was significantly different (Duncan's test; $\mathrm{P}<0.05$ ).

Table 3. Dosage of barramundi seed seven days post-vaccination on seed treatment injected bivalent vaccine (V), seed injected PBS (K)

\begin{tabular}{cccccc}
\hline Treatment & $\begin{array}{c}\text { E Erythrocyte } \\
\left(\times 10^{6} \text { cell/mm }\right)\end{array}$ & $\begin{array}{c}\text { E Leucocyte } \\
\left(\times 10^{4} \text { cell/mm }\right)\end{array}$ & $\begin{array}{c}\text { Hb } \\
(\mathrm{g} / \mathrm{dL})\end{array}$ & $\begin{array}{c}\text { Hc } \\
(\%)\end{array}$ & $\begin{array}{c}\text { AF } \\
(\%)\end{array}$ \\
\hline Initial & $3.81 \pm 0.00^{\mathrm{bc}}$ & $3.15 \pm 0.00^{\mathrm{a}}$ & $12.00 \pm 0.00^{\mathrm{a}}$ & $15.10 \pm 0.12^{\mathrm{b}}$ & $24.00 \pm 0.00^{\mathrm{a}}$ \\
Vaccine & $4.09 \pm 0.20^{\mathrm{c}}$ & $6.31 \pm 0.10^{\mathrm{c}}$ & $13.67 \pm 0.00^{\mathrm{b}}$ & $15.89 \pm 0.14^{\mathrm{b}}$ & $29.00 \pm 1.73^{\mathrm{c}}$ \\
Control & $3.62 \pm 0.41^{\mathrm{a}}$ & $3.43 \pm 0.09^{\mathrm{b}}$ & $12.67 \pm 0.58^{\mathrm{a}}$ & $14.99 \pm 1.03^{\mathrm{a}}$ & $23.00 \pm 1.53^{\mathrm{b}}$ \\
\hline
\end{tabular}

Note: Hemoglobin (Hb), hematocrit (Hc), phagocytic activity (AF), different superscript on the age of the seed and the same parameters indicated significant different (Duncan's $\mathrm{P}<0.05$ ). 
Table 4. Blood profile barramundi seed 7 days post-challenge with the injected bivalent vaccine (V), and injected with PBS (K), respectively tested challenge with bacteria P. stutzeri, V. harveyi, combined of P. stutzeri and V. harveyi, and control

\begin{tabular}{ccccccc}
\hline Treatment & $\begin{array}{c}\text { Challenge } \\
\text { test }\end{array}$ & $\begin{array}{c}\text { E Erythrocyte } \\
\left(\times 10^{6} \text { cell/mm }\right)\end{array}$ & $\begin{array}{c}\sum \text { Leucocyte } \\
\left(\times 10^{4} \text { cell/mm }\right)\end{array}$ & $\begin{array}{c}\mathrm{Hb} \\
(\mathrm{g} / \mathrm{dL})\end{array}$ & $\begin{array}{c}\mathrm{Hc} \\
(\%)\end{array}$ & $\begin{array}{c}\text { AF } \\
(\%)\end{array}$ \\
\hline \multirow{2}{*}{ Vaccine } & $P$. stutzeri & $2.62 \pm 0.16^{\mathrm{c}}$ & $6.35 \pm 0.21^{\mathrm{b}}$ & $12.00 \pm 0.00^{\mathrm{cd}}$ & $14.29 \pm 0.95^{\mathrm{d}}$ & $34.00 \pm 1.00^{\mathrm{c}}$ \\
& V. harveyi & $2.35 \pm 0.28^{\mathrm{bc}}$ & $6.80 \pm 0.28^{\mathrm{b}}$ & $12.00 \pm 0.00^{\mathrm{cd}}$ & $11.99 \pm 0.60^{\mathrm{c}}$ & $35.00 \pm 1.00^{\mathrm{c}}$ \\
& Combination & $2.10 \pm 0.16^{\mathrm{b}}$ & $6.85 \pm 1.20^{\mathrm{b}}$ & $11.00 \pm 0.00^{\mathrm{b}}$ & $9.81 \pm 0.71^{\mathrm{b}}$ & $38.50 \pm 1.53^{\mathrm{d}}$ \\
Control & $P$. stutzeri & $1.48 \pm 0.30^{\mathrm{a}}$ & $4.55 \pm 0.07^{\mathrm{a}}$ & $10.33 \pm 0.58^{\mathrm{a}}$ & $9.78 \pm 1.11^{\mathrm{b}}$ & $30.50 \pm 1.53^{\mathrm{b}}$ \\
& V. harveyi & $1.39 \pm 0.08^{\mathrm{a}}$ & $4.55 \pm 0.07^{\mathrm{a}}$ & $10.67 \pm 0.58^{\mathrm{ab}}$ & $7.96 \pm 0.06^{\mathrm{a}}$ & $29.00 \pm 1.00^{\mathrm{ab}}$ \\
& Combination & $1.33 \pm 0.13^{\mathrm{a}}$ & $4.60 \pm 0.14^{\mathrm{a}}$ & $11.33 \pm 0.58^{\mathrm{bc}}$ & $7.84 \pm 0.42^{\mathrm{a}}$ & $29.00 \pm 1.00^{\mathrm{ab}}$ \\
\hline
\end{tabular}

Note: Hemoglobin (Hb), hematocrit (Hc), phagocytic activity (AF). Different superscript on the age of seeds and similar parameters indicated significant different treatment effects (Duncan's test; $\mathrm{P}<0.05$ ).
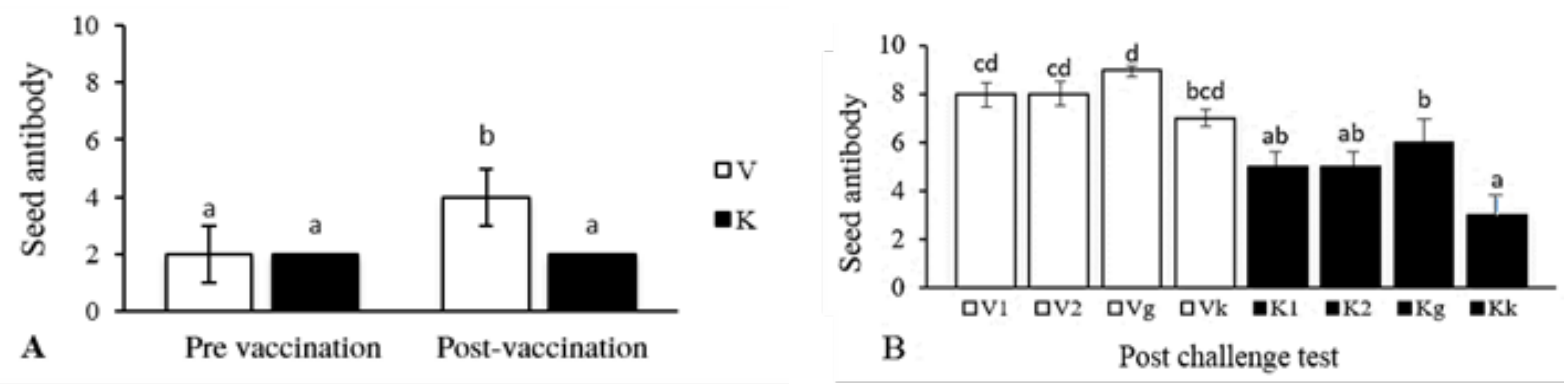

Figure 1. A. Antibody titer of barramundi seed pre-vaccination and seven days post-vaccination using bivalent vaccine (V), and injected PBS (K). B. Antibody titer of barramundi seed seven days post-challenge which injected using P. stutzeri (1), V. harveyi (2), the combination of P. stutzeri and V. harveyi (g), and control (k). Different superscript in each bar indicated the treatment was significantly different (Duncan's $\mathrm{P}<0.05$ ).

of fish vaccine with the range of $9.81-14.29 \%$ there is no difference $(\mathrm{P}>0.05)$ with the control fish group in the range of $7.84-9.78 \%$ among all treatments. The blood profile barramundi of seventh-day post-banding is presented in Table 4.

\section{Antibody titer post-vaccination and challenge test of barramundi seed}

Giving vaccine in barramundi seed had a significant effect $(\mathrm{P}<0.05)$ to the titer value of barramundi seed antibody during the rearing period. The antibody of vaccinated fish increased by two to four on day seventh after vaccination and significantly higher $(\mathrm{P}<0.05)$ than control treatment that was not increased. Provision of the vaccine in barramundi seed was also influential significant to barramundi seed antibodies tested challenge with P. stutzeri bacteria (1), $V$. harveyi (2), a combination of $P$. stutzeri and $V$. harveyi $(\mathrm{g})$, and PBS $(\mathrm{k})$. The antibody titer of each treatment is presented in Figure 1.

\section{Lysozyme activity of barramundi seed after vaccination and challenge test}

The lysozyme activity of bivalent vaccinated seed was significantly higher on day 7 post vaccination compared with control treatment $(\mathrm{P}<0.05)$. Vaccine also effected the lysozyme activity of barramundi seed after the challenge test. Lysozyme activity of vaccinated fish which challenge with $P$. stutzeri bacteria (1), $V$. harveyi (2), combination of $P$. stutzeri and $V$. harveyi (g), and PBS (k) were significantly higher than the control challenge against the same bacteria. Lysozyme activity of barramundi seed after vaccination is presented in Figure 2.

\section{Histopathological observation}

The histopathology result of barramundi fish after challenge test showed the presence of microscopic anatomical pathology difference in both treatment and control experimental fish using the combination bivalent vaccine $P$. stutzeri and $V$. harveyi (Figure $3 \mathrm{~A} \& 3 \mathrm{~B}$ ). It was noticed in Figure $3 \mathrm{~A}$ that hepatocytes was healthy and normal, whereas in Figure 3B most of the hepatocytes experienced necrosis. The histology profile of the experimental barramundi is presented on Figure 3. 

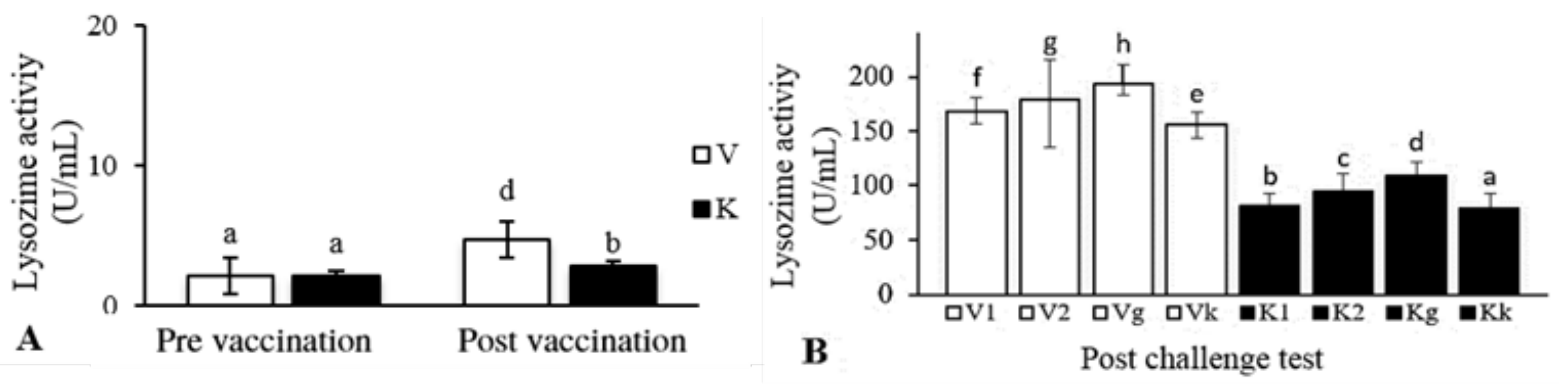

Figure 2. Lysozyme activities of barramundi before vaccination (early), as well as on seven days post vaccination with bivalent vaccine injection (V) and control treatment the PBS (K) injection (A); Lysozime activity of barramundi seed seven days post challenges that were injected by P. stutzeri bacteria (1), V. harveyi (2), P. stutzeri and $V$. harveyi $(\mathrm{g})$, and control $(\mathrm{k})(\mathrm{B})$. Different superscript in each bar indicated the effect of treatment was significantly different (Duncan's $\mathrm{P}<0.05$ )
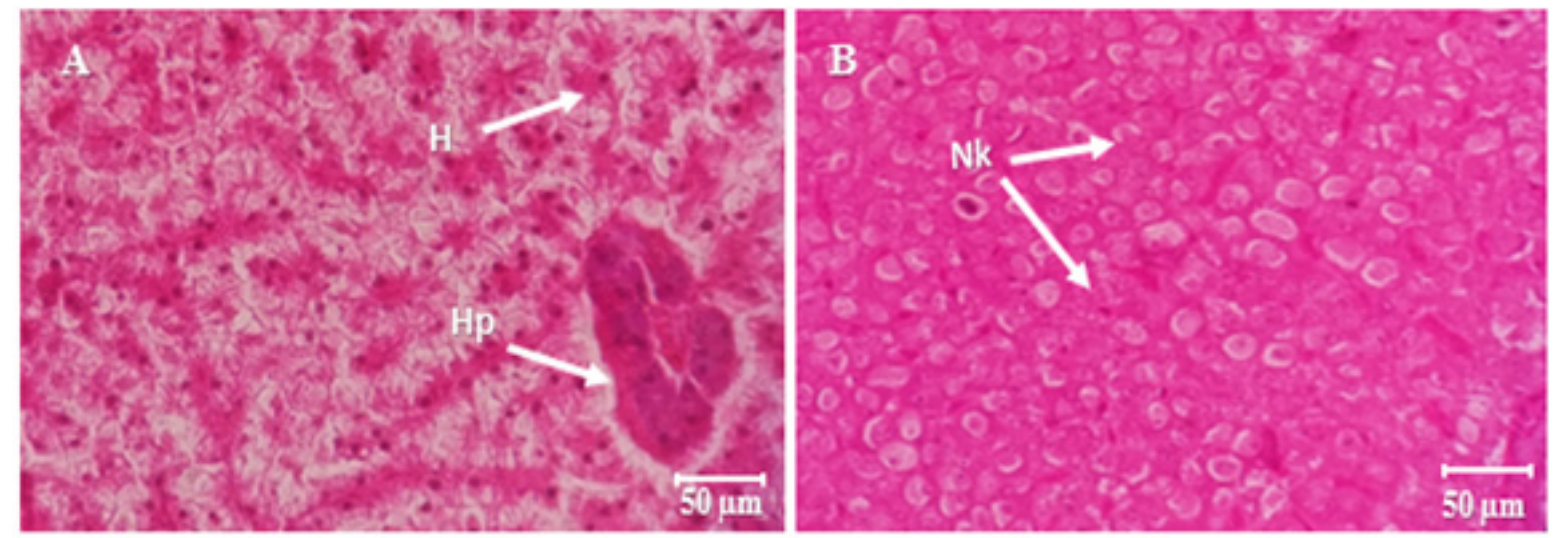

Figure 3. Microscopic anatomical pathology of liver tissue of barramundi on $7^{\text {th }}$ day after a combined bacterial infection of $P$. stutzeri and $V$. harveyi: A) Liver tissue of barramundi that was vaccinated and challenged test with the combined bacteria was normal and still had nucleus with normal hepatopancreas; B) Liver tissue of barramundi injected with PBS and challenge tested using combined bacteria experienced necrosis (Nk).

\section{DISCUSSION}

Vaccination is a prevention method made from antigens derived from pathogens and made nonpathogenic through various ways which stimulates the specific immunity to control infectious diseases in fish, such as bacteria and virus attacks, and has been proven significantly in preventing disease outbreaks, and it also has low cost (Roar \& Muiswinkel, 2013; Wali \& Balkhi, 2016; Ayalew \& Abunna, 2018; Shefat, 2018). Health status of vaccinated fish immunity becomes one of the prove of fish health status and determine the relation with fish immune conditions before and after vaccination to demonstrate efficacy and extent protection of the vaccine (Tobar et al., 2015). Bivalent vaccine can protect barramundi with RPS up to $80.00 \%$ when challenged with $P$. stutzeri bacteria, $64.29 \%$ when challenged with $V$. harveyi, $57.69 \%$ when challenged with combined bacteria. Mulia (2007) stated that the vaccine was considered to be effective if relative survival yields more than $50 \%$. Results research showed that applying the bivalent vaccine was effective in protecting the barramundi seeds towards BBS. Bivalent vaccination is effective in the protection against single or combined bacterial infections. It is one of the advantages of using a multivalent vaccine. The utilization of one dose of vaccine containing many antigens affects the effectivity and reduces the stress of the fish (Shoemaker et al., 2012).

The low mortality rate and the relatively high survival rate of vaccination treatment were generally caused by the formation of a non-specific immune response followed by specific immune enhancement. The specific immune formation was indicated by increased levels of antibodies. Besides the formation of specific immune as well as indicated by the activity of T cells ( $\mathrm{T}$ helper cells, cytotoxic $\mathrm{T}$ cells, and $\mathrm{T}$ memory cells) and $\mathrm{B}$ cells (B-cell memory and cell plasma). The B cell memory would store information about the antigenic characteristics that enter the body while the cell $>$ s plasma would produce a specific antibody to the antigen. Antigens that entered 
the body was engulfed by macrophages. Once it was engulfed, the antigen will be exposed to the $\mathrm{T}$ helper cells through protein major histocompatibility complex (MHC) class II. The $\mathrm{T}$ helper cells will activate by macrophages through cytokine molecules. After being activated with cytokines from macrophages, the helper will produce cytokines that stimulate $\mathrm{B}$ cells, $\mathrm{T}$ cells memory, and cytotoxic $\mathrm{T}$ cells. When the identical antigen exposes for the second time, $\mathrm{T}$ cell memory will stimulate B cell memory to proliferate into cell plasma and produce antibody. The nonspecific immune response is indicated through the congenital body defense system and hematological parameters (Reece et al., 2014).

The blood profile parameters have been used as indicators of health status in some species (Santos et al., 2009; Adedeji, 2010; Akinrotimi et al., 2012; Sayed \& Moneeb, 2015). One of the parameters to indicate fish health status is the total of erythrocytes. The value of erythrocytes after the challenge test was known to decrease in all treatments, especially in the control treatment. This was presumably because one of the bacteria used in the challenge test ( $V$. harveyi) can break red blood cells so that levels of erythrocytes tend to decline. Minasyan (2014) stated that hemoglobin helps kill bacteria, that happens when erythrocytes are lysed by bacteria their hemoglobin releases free radicals which break down the pathogen's cell wall and membrane, killing it. For hematocrit, Sukenda et al. (2014) were reported that the hematocrit on vaccinated fish had no significant effect on fish health status. However, there was an effect on the total leucocytes and phagocytic activity of vaccinated fish. Results of blood profile post-vaccination still showed a normal value. However, the health status of barramundi vaccinated using the bivalent vaccine was greater than other treatments post-vaccination or after the challenge test. The result was noticed in the total leucocytes and phagocytic activity in vaccinated barramundi seed has a significantly higher value compared to control treatment. This was suspected because the antibody titer of vaccinated treatments was significantly higher than the control treatment. According to Reece et al. (2014) antibody might bind to the antigen on the surface of the bacteria cell thus it blocks the site of bacteria recognition on its host and facilitates phagocytosis. The antibody that binds to the antigens on the surface of bacteria cells is also capable of forming complexes with protein complements. These protein complements will insert into the bacterial cell membrane and form a pore which then lyses the cell target. Nonspecific body defense systems, such as phagocytic activity and lysozyme activity, also play a role in reducing the exposure of $P$. stutzeri and $V$. harveyi bacteria in the fish body.

The immune response represents the immune conditions of the fish, both specific and nonspecific immune system. The specific immunity that can show the efficacy level of the vaccine is the value of the antibody titer. The results showed that the administration of the vaccine in barramundi gives a significantly effective than unvaccinated seeds. The results of antibody titer measurements in two groups (vaccine and control) showed that there was an increase of antibody titer in the vaccinated treatment after vaccination which reached a value of 4 compared to the group of fish injected with PBS (K) during the rearing period after vaccination (day 7) (Figure 1). Raida et al. (2011) stated that whole vaccines which put into the fish body intraperitoneally increased specific antibody compared to unvaccinated fish. This matter showed that vaccination was the potential to induce specific antibody responses. Sun et al. (2014) added that the application of $V$. harveyi vaccine was injected to Parachthys olivaceus seeds, was able to support its survival when tested using $V$. harveyi and $S$. iniae. Comparing with mortality data in Table 2, the vaccinated group shows the lowest mortality percentages, as well as the antibody titers data (Figure 1). This result same to Villumsen et al. (2012); Romstad et al. (2013); Marana et al. (2017) that stated if antibody titers are related to survival rate between unvaccinated fish and vaccinated fish.

Lysozyme is a bacteriolytic enzyme produced in lysosomes in phagocyte cells, suggesting that lysozyme plays a conserved role in host defense across the animal kingdom. Lysozyme works by destroying bacterial cells via targeted hydrolysis of bacterial cell walls, which are critical for the resistance of bacteria to osmotic stress (Callewaert \& Michiels, 2010; Uribe et al., 2011; Ragland \& Criss, 2017). Lysozyme activity of barramundi seed on the seventh day after vaccination between the treatment of bivalent vaccines and controls was significantly different $(\mathrm{P}<0.05)$. The activity of lysozyme seeds injected by the bivalent vaccine increased rapidly compared with nonvaccinated control. This was indicated by a considerable value between vaccine and control treatments on day seven after vaccination of (4.69 U/ $\mathrm{mL}(\mathrm{V})$ and $2.79 \mathrm{U} / \mathrm{mL}(\mathrm{K})$ ). A similar thing also occurred after the challenge test. Barramundi's 
seed on bivalent vaccine treatment tested with $P$. stutzeri (1), V. harveyi (2), combined $P$. stutzeri and $V$. harveyi $(\mathrm{g})$, and the control of PBS (k) had higher lysozyme activity compared with control treatments that tested against the same bacteria. The activity of lysozyme after the highest challenge test is obtained by the combined Vg (combined) treatment showed that bivalent vaccinated seeds were then tested with $P$. stutzeri and $V$. harveyi which can induce nonspecific immune systems with lysozyme values of $193.79 \mathrm{U} / \mathrm{mL}$. It was suggested that vaccination did not only improve specific immune responses but also enhances nonspecific immune. The utilization of the bivalent vaccine in barramundi's seed also affected the condition of microscopic internal organs. Figure 3A showed the liver organ of the bivalent combination vaccine had plenty of normal and healthy hepatocyte cells at $7^{\text {th }}$ the challenge test, while Figure $3 \mathrm{~B}$ is the treatment of fish seed injected by PBS and tested against combined bacteria. Both of them took on the same day and of the two there are differences with the number of necrotic hepatocyte cells. The result of research from El-Sharaby et al. (2018), are known that the histopathological examination of the livers naturally infected fishes by Vibrio showed necrosis of hepatocytes, necrotic means the death of cells or tissues caused by diseases. Healthy liver cells in Figure 3A showed that bivalent vaccines can protect fish from necrotic cells and mortality.

\section{CONCLUSION}

Bivalent vaccines were effective in controlling BBS disease in terms of the value of RPS on all treatments which was more than $50 \%$. The bivalent vaccine of $P$. stutzeri and $V$. harveyi bacteria potentially protected the barramundi seed to prevent BBS disease outbreak.

\section{REFERENCES}

Adedeji OB. 2010. Acute effect of diazinon on blood plasma biochemistry in the African catfish Clarias gariepinus. Journal of Clinical Medicine \& Research 2: 1-6.

Akinrotimi OA, Agokei EO, Aranyo AA. 2012. Changes in blood parameters of tilapia guineensis exposed to different salinity levels. Journal of Environmental Engineering \& Technology 1: 4-12.
AndersonDP,Siwicki AK. 1993. Basichematology and serology for fish health programs. Paper presented in second symposium on diseases in asia aquaculture "Aquatic Animal Health and The Environmental". Phuket Thailand. 25-29 $9^{\text {th }}$ October 1993.

Assefa A, Abunna F. 2018. Maintenance of fish health in aquaculture: review of epidemiological approaches for prevention and control of infectious disease of fish. Veterinary Medicine International 18: 1-10.

Ayalew A, Abunna F. 2018. Maintenance of fish health in aquaculture: review of epidemiological approaches for prevention and control of infectious disease of fish. Veterinary Medicine International 18: 1-10.

Blaxhall PC, Daisley KW. 1973. Routine haemotologycal methods for use with fish blood. Journal Fish Biology 5: 577-581.

Callewaert L, Michiels CW. 2010. Lysozymes in the animal kingdom. Journal of Bioscience 35: 127-60.

Dong HT, Jitrakorn S, Kayansamruaj P, Pirarat N, Rodkhum C, Rattanarojpong T, Saksmerprome V. 2017. Infectious spleen and kidney necrosis disease (ISKND) outbreaks in farmed barramundi (Lates calcarifer) in Vietnam. Fish \& Shellfish Immunology 68: 65-73.

Ellis AE. 1990. Lysozyme assays. In: Stolen JS, Fletcher TC, Anderson PD, Roberson BS, Muiswinkel WB: Technique in fish immunology. SOS Publications 101-103.

El-Sharaby SMA, Abd-Elgaber M, Tarabees R, Khalil RH, Ali MN, El-Ballal S. 2018. Bacteriological and histopathological studies on Vibrio species isolated from naturally infected freshwater fish in Delta Region, Egypt. Advances in Animal and Veterinary Sciences 6: 17-26.

Evensen O, Leong JA. 2013. DNA vaccines against viral diseases of farmed fish. Fish Shellfish Immunology 35: 1-8.

Hamed SB, Paiva MJTR, Tachibana L, Dias DC, Ishikawa CM, Esteban MA. 2018. Fish pathogen bacteria: adhesion, parameters influencing virulence and interaction with host cells. Fish \& Shellfish Immunology 80: 550-562.

Izwar A. 2018. Isolation, identification, and pathogenicity tests of pathogenic bacterial associated with black body syndrome in barramundi Lates calcarifer B. [Thesis]. Bogor: IPB University. 
Kubecka J, Boukal DS, Cech M, Hickley P, Kitchell JF, Ricard D, Rudstam L, Soukalova K, Welcomme R. 2016. Ecology and ecological quality of fish in lakes and reservoirs. Fisheries Research 173: 1-3.

Kumaran S, Deivasigamani B, Alagappan KM, Sakthivel M. 2010. Infection andimmunization trials of Asian seabass Lates calcarifer against fish pathogen Vibrio anguillarum. Journal of Environmental Biology 31: 539-541.

Marana MH, Jorgensen LG, Skov J, Chettri JK, Mattsson AH, Dalsgaard I, Kania PW, Buchmann K. 2017. Subunit vaccine candidates against Aeromonas salmonicida in rainbow trout Oncorhyncus mykiss. PLos ONE 12: 1-15.

Minasyan H. 2014. Erythrocyte and blood antibacterial defense. European Journal of Microbiology and Immunology 4: 138-143.

Mulia DS. 2007. Efficacy of Aeromonas hydrophila vaccine to control motile aeromonas septicemia (MAS) disease on gouramy (Osphronemus gouramy Lac.). Jurnal Pembangunan Pedesaan 7: 43-52.

Ozturk RC, Altinok I. 2014. Bacterial and viral fish disease in turkey. Turkish Journal of Fisheries and Aquatic Sciences 14: 275-297.

Ragland SA, Criss AK. 2017. From bacterial killing to immune modulation: Recent insights into the functions of lysozyme. Plos Pathogen 13: 1-22.

Raida MK, Nylen J, Andersen LH, Buchmann K. 2011. Association between plasma antibody response and protection in Rainbow Trout Oncorhynchus mykiss immersion vaccinated against Yersinia ruckeri. PLos ONE 6: 1-7.

Ransangan J, Saleem M. 2009. Identification of Vibrio harveyi isolated from diseased Asian seabass Lates calcarifer by use of $16 \mathrm{~S}$ ribosomal DNA sequencing. Journal of Aquatic Animal Health 21: 150-155.

Ransangan J, Manin BO. 2010. Mass mortality of hatchery produced larvae of Asian seabass, Lates calcarifer (Bloch), associated with viral nervous necrosis in Sabah, Malaysia. Veterinary Microbiology 145: 153157.

Ransangan J, Lal TM, Al-Harbi AH. 2012. Characterization and experimental infection of Vibrio harveyi isolated from diseased Asian seabass (Lates calcarifer). Malays.Journal Microbiol 8: 104-115.

Reece JB, Urry LA, Cain ML, Wasserman SA, Minorsky PV, Jacson RB. 2014. Campbell
Biology. New York (US): Pearson Education.

Rico A, Satapornvanit K, Haque MM, Min J, Nguyen PT, Telfer TC, Brink PJ. 2012. Use of chemicals and biological products in Asian aquaculture and their potential environmental risks: a critical review. Reviews in Aquaculture 4: 75-93.

Roar G, Muiswinkel BV. 2013. A history of fish vaccination: science-based disease prevention in aquaculture". Fish and Shellfish Immunology 35: 1683-1688.

Romstad AB, Reitan LJ, Midtlyng P, Gravningen K, Evensen. 2013. Antibody responses correlate with antigen dose and in vivo protection for oil-adjuvanted, experimental furunculosis (Aeromonas salmonicida subsp. salmonicida) vaccines in Atlantic salmon (Salmo salar L.) and can be used for batch potency testing of vaccines. Vaccine 31: 791796.

Santos AA, Ranzani-Paiva MJT, Veiga ML, Faustino L, Egami MI. 2009. Hematological parameters and phagocytic activity in fat snook Centropomus parallelus bred in captivity. Fish \& Shellfish Immunology 33: 953-961.

Sayed AEH, Moneeb RH. 2015. Hematological and biochemical characters of monosex tilapia Oreochromis niloticus Linnaeus 1758 cultivated using methyltestosterone. The Journal of Basic \& Applied Zoology 72: 3642.

Sharma SRK, Rathore G, Verma DK, Sadhu N, Philipose KK. 2012. Vibrio alginolyticus infection in Asian seabass (Lates calcarifer, Bloch) reared in open sea floating cages in India. Aquaculture Research 44: 86-92.

Shefat SHT. 2018. Vaccines for use in finfish aquaculture. Acta Scientific Pharmaceutical Sciences 2: 15-19.

Shoemaker CA, LaFrentz BR, Klesius PH. 2012. Bivalent vaccination of sex reversed hybrid tilapia against Streptococcus iniae and Vibrio vulnificus. Aquaculture 354: 45-49.

Siddik MAB, Islam MA, Hanif MA, Chaklader MR, Kleindienst R. 2016. Barramundi, Lates calcarifer (Bloch, 1790): A new dimension to the fish farming in Coastal Bangladesh. Journal of Aquaculture Research \& Development 7: $1-3$.

Sukenda, Febriansyah TR, Nuryati S. 2014. Whole-cell vaccine of Streptococcus agalactiae in Oreochromis sp. with immersion method. Jurnal Akuakultur Indonesia 13: 8393. 
Sun BG, Dang W, Sun L, Hu YH. 2014. Vibrio harveyi Hsp70: immunogenicity and application in the development of an experimental vaccine against $V$. harveyi and Streptococcus iniae. Aquaculture 418: 144147.

Takahashi JD, Montassier HJ, Takahashi LS, Urbinati EC. 2014. Proposed method for agglutinating antibody titer analysis and its use as indicator of acquired immunity in pacu, Piaractus mesopotamicus. Brazil Journal Biology 74: 238-242.

Tobar I, Arancibia S, Torres C, Vera V, Soto P. 2015. Successive oral immunizations against Piscirickettsia salmonis and infectious salmon anemia virus are required to maintain a longterm protection in farmed salmonids. Frontiers in Immunology 6: 1-7.

Uribe C, Folch H, Enriquez R, Moran G. 2011. Innate and adaptive immunity in teleost fish: a review. Veterinary Medicine 56: 486-503.

Venkatachalam S, Kandasamy K, Krishnamoorthy I, Narayanasamy R. 2018. Survival and growth of fish (Lates calcarifer) under integrated mangrove-aquaculture and open aquaculture systems. Aquaculture reports 9: 18-24.

Villumsen KR, Dalsgaard I, Andersen LH, Raida MK. 2012. Potential role of specific antibodies as important vaccine induce protective mechanism against Aeromonas salmonicida in Rainbow Trout. PlosOne 7: 1-6.

Wali A, Balkhi MUH. 2016. Fish vaccination and therapeutics. International Journal of Multidiciplinary Research and Development 3: 55-60.

Wedemeyer IWT, Yasutake WT. 1977. Clinical methods for the assessment of the effect on environmental stress on fish health. Journal Fish \& Wildlife Service 89: 1-17. 